UDC 378

DOI https://doi.org/10.24919/2308-4863/36-2-32

\author{
Olha KOTOVA, \\ orcid.org/0000-0002-5533-3844 \\ Candidate of Physical and Mathematical Sciences, Associate Professor, \\ Associate Professor at the Department of Algebra, Geometry and Mathematical Analysis \\ Kherson State University \\ (Kherson,Ukraine) olga-kotova@ukr.net \\ Valentyna HRYHORIEVA, \\ orcid.org/0000-0002-7388-4287, \\ Candidate of Pedagogical Sciences, \\ Senior Lecturer at the Department of Algebra, Geometry and Mathematical Analysis \\ Kherson State University \\ (Kherson, Ukraine)vb.grigorieva@gmail.com
}

Olha HNIEDKOVA, orcid.org/0000-0001-5194-2194,

Candidate of Pedagogical Sciences,

Associate Professor at the Department of Informatics, Software Engineering and Economic Cybernetics

Kherson State University

(Kherson, Ukraine) gnedkova84@gmail.com

\title{
LINEAR ALGEBRA TEACHING USING MATHEMATICS SOFTWARE PACKAGES
}

Mathematics software packages using is one of the indicators of professional learning level of university graduates in information computer technologies (ICT). The problems of linear algebra are easy to algorithmize. To increase the efficiency of students' professional competencies formation, it is necessary to talk about algorithms in the form they would be performed by a computer. The ICT use in linear algebra teaching is becoming relevant. The main types of educational software are electronic textbooks, mathematics software packages and monitoring software. Electronic textbooks are used at lectures. There are textbooks with built-in knowledge control tools. Some textbooks contain practical tasks. However, there is no the educational virtual environment for practical tasks performing. Mathematics software packages Mathematica, Maple, MathCAD, Matlab are used at practical classes. Mathematics software packages will automate arithmetic calculations and enable students to focus on the essence of method. Monitoring software diagnoses checks and evaluates the knowledge, abilities and skills of the student. The linear testing algorithm is the simplest. For each student, a test variant is generated in a random order from the task repository. At linear and randomized testing, all participants have test questions of the same complexity. For example, the Google Forms service is widely available; it allows randomizing responses and uploading data in Excel format. The experience of Matlab package using in the linear algebra for students of "Software Engineering" specialty is presented in the article. Practical realization of main topics of linear algebra is developed in this package. The methodical features of the package application in solving the most algorithmic problems of the course are revealed. In particular, problems in the theory of matrices and determinants and systems of linear equations.

Key words: study of linear algebra, software packages in mathematics.

Ольга КОТОВА, orcid.org/0000-0002-5533-3844 кандидат фізико-математичних наук, доцент, доиент кафедри алгебри, геометрії та математичного аналізу

Херсонського державного університету (Херсон, Україна) olga-kotova@ukr.net

Валентина ГРИГОР'СВА, orcid.org/0000-0002-7388-4287 кандидат педагогічних наук, старший викладач кафедри алгебри, геометрї та математичного аналізу

Херсонського державного університету (Херсон, Украӥна)vb.grigorieva@gmail.com 


\author{
Ольга ГНЕДКОВА, \\ orcid.org/0000-0001-5194-2194 \\ кандидат педагогічних наук, \\ доцент кафедри інформатики, програмної інженерії та економічної кібернетики \\ Херсонського державного університету \\ (Херсон, Україна) gnedkova84@gmail.com
}

\title{
НАВЧАННЯ ЛІНІЙНОЇ АЛГЕБРИ З ВИКОРИСТАННЯМ МАТЕМАТИЧНИХ ПРОГРАМНИХ ЗАСОБІВ
}

\begin{abstract}
Використання програмнихзасобівз математики єодним із показників рівня професійного навчання випускників університетів з інформаційних комп'ютерних технологій (IКT). Задачі лінійної алгебри легко алгоритмізувати. Для підвищення ефективності формування професійних компетентностей студентів необхідно говорити про алгоритми у тому вигляді, в якому би його виконував комп'ютер. Використання IКТ у навчанні лінійної алгебри стає актуальним. Основними типами навчального програмного забезпечення є електронні підручники, пакети програм з математики та програмне забезпечення для моніторингу. На лекиіях використовуються електронні підручники. $\epsilon$ підручники із вбудованими засобами контролю знань. Деякі підручники містять практичні завдання. Однак не існує освітнього віртуального середовища для виконання практичних завдань. На практичних заняттяях використовуються програмні пакетні засоби з математики Mathematica, Maple, MathCAD, Matlab. Пакетні програми з математики автоматизують арифметичні обчислення та дають змогу студентам зосередитись на суті методу. Програмне забезпечення для моніторингу діагностує перевірку та оиінюе знання, вміння та навички студента. Алгоритм лінійного тестування є найпростішим. Для кожного студента тестовий варіант генерується у довільному порядку зі сховища завдань. Під час лінійного та рандомізованого тестування всі учасники мають тестові запитання однакової складності. Наприклад, сервіс Google Forms широко доступний; ие дозволяє рандомізувати відповіді та завантажувати дані у форматі Ехсеl. У статті представлений досвід використання пакета Matlab у лінійній алгебрі для студентів спеиіальності «Програмна інженерія». Практична реалізація основних тем лінійної алгебри розроблена у иъому пакеті. Розкрито методичні особливості застосування пакета під час розв'язування найбільш алгоритмічних завдань з курсу. Зокрема, задач з теорії матриць та визначників і систем лінійних рівнянь.
\end{abstract}

Ключові слова: навчання лінійної алгебри, пакетні засоби з математики.

Introduction. The priority directions of modern society development is educational process improvement on the basis of new information computer technologies (ICT) introduction. The ICT use in the educational process involves not only the learning of the ways of ICT mastering and developing, but ICT use in a specific subject area, in particular, for training of solving tasks through various packages of applications (Mathematica, Maple, MathCAD, Matlab) (Stormy Attaway, 2009).

The programming language Matlab was developed by Cleve Moler, the Dean of Computer Science Department of New Mexico University in the late 1970s. John Little together with Cleve Moler and Steve Bangert rewrote Matlab in C programming language and founded The MathWorks. At the moment, Matlab is a high-level language and interactive environment for developing algorithms, calculations, visualization and data analysis. It was originally developed for control systems designing. Matlab has quickly gained popularity in many scientific and engineering areas. Matlab package is an effective in the educational process, in particular, linear algebra teaching. In 2004, the Ministry of Education and Science of Ukraine decided to implement Matlab in the senior classes and universities. According to the UNESCO ICT Competency System, teachers who have sufficient competencies in ICT using in their professional practice will be able to ensure a high level of educational quality and effectively promote students' ICT competences development (Terms of use - CC BY SA).

Matlab environment use in diploma theses and dissertations will increase the complexity and importance of research. It will significantly redistribute the workload of teachers-from homework tasks assessment to network project management in Matlab environment. For example, Eindhoven Technical University in the Netherlands (Technische Universiteit Eindhoven), the most parts of scientific and teaching equipment are designed by students and produced within the educational process. So, it saves funds for the purchase of laboratory equipment.

Related works. IT implementation in education is constantly being researched by scientists of international organizations: UNESCO, UN, European Union, Council of Europe and others. The researches of S. Peipert, M. Reznik, E. Patarakin, E. Polat, A. Khutorsky, B. Yarmakhov, A. Yastrebtsev are devoted to this problem. V. Bykov, N. Zhaldak, N. Zgurovskyi, V. Kukharenko, V. Lapinsky, N. Morse, A. Pilipchuk, S. Rakova, S. Semerikov, E. Slovak, A. Stryuk, M. Shishkina and others are exploring the IT use in educational process. 
Matlab is one of the ICT student's educational tools. On May 16, 2019, the First International Scientific and Practical Conference "Matlab and Computer Computing in Education, Science and Engineering" was held at the Kiev National Aviation University. Currently, there is an enough literature of self-study tools and its use in education process.

The main purpose of the article is to consider the experience of using the Matlab package in linear algebra for students majoring in "Software Engineering".

Matlab package use in linear algebra learning. Students of computer specialties who have completed the linear algebra course should:

- understand the basic ideas of linear algebra, the role of the methods in applications of other sciences, their practical introduction and capabilities;

- possess theoretical knowledge in solving of linear equations, the theory of arithmetic linear spaces and the theory of linear operators on arithmetic linear spaces, theory of polynomials in one and several variables;

- orient in the linear algebra information flown;

- acquire skills in solving typical tasks of linear algebra.

For example, typical tasks are: finding a solution of linear equation systems, calculating the values of determinants and the matrix rank, finding a linear operator matrix, studying the roots of polynomials in one variable.

Since linear algebra tasks are easy to algorithmize, their implementation in the mathematical package Matlab is possible.

Let's consider matrices. Matrix elements are given in square brackets. Elements of one line are separated from each other by a space or comma. Lines are separated by a semicolon. The matrix name and element indices in parentheses should be specified.

Basic operations with matrices:

1. $\mathrm{A}+\mathrm{B}$ addition of matrices $\mathrm{A}$ and $\mathrm{B}$ (operation is possible with the same order of the matrices).

2. A - B subtracting of matrices A and B (operation is possible with the same order of matrices).

3. $\mathrm{A} * \mathrm{~B}$ is matrices product (an operation is possible when the number of columns of the matrix $\mathrm{A}$ is equal to the number of rows of the matrix $\mathrm{B}$. The operation is not commutative).

4. A.* In the element wise multiplication of the matrices $\mathrm{A}$ and $\mathrm{B}$ of the same dimension.

5. A./B element wise division of the matrices $\mathrm{A}$ and $\mathrm{B}$ of the same dimension.

6. $\mathrm{A}^{\wedge} \mathrm{k}$ element wise raising of an array to $\mathrm{k}$ degree;

7. A 'transposition of matrix A.

8. $A^{\wedge}-1$ (or inv (A)) calculation of the inverse matrix $\mathrm{A}^{-1}$ (the inverse matrix exists for square matrices whose determinant is nonzero).
9. $\operatorname{det}(\mathrm{A})$ calculating of the matrix A determinant.

10. size (A) Definition of the matrix A dimension.

11. trace (A) the sum of the elements on the main diagonal.

12. sum (A) the sum of the elements in each matrix A column.

13. $\operatorname{prod}(\mathrm{A})$ is the product of the elements in each column of the matrix A.

14. $\operatorname{diag}(\mathrm{A})$ the column vector of the elements of the matrix A main diagonal.

15. sort (A) sorting of matrix A each column.

16. max (A) calculating the maximum in matrix A each column.

17. min (A) calculation of the minimum in matrix A each column.

18. mean (A) calculation of the average value in matrix A each column.

19. $\operatorname{rot} 90$ (A) rotation of matrix A to the left by $90^{\circ}$.

20. fliplr (A) flip of matrix A from left to right.

21. flipud (A) flip of matrix A from top to bottom.

22. $A(n,:)=[]$ deletion of the row number $n$ from matrix A.

Example

Let's consider the example. Matrices are given

$$
A=\left(\begin{array}{ccc}
-3 & 5 & 13 \\
11 & -5 & 7 \\
2 & -1 & -6
\end{array}\right), B=\left(\begin{array}{ccc}
2 & 9 & -8 \\
1 & -15 & 14 \\
4 & -12 & 3
\end{array}\right)
$$

Let's calculate

$\mathrm{A}+\mathrm{B}, \mathrm{A}-\mathrm{B}, \mathrm{A} \cdot \mathrm{B}, \mathrm{B} \cdot \mathrm{A},|\mathrm{A}|,|\mathrm{B}|, \mathrm{A}^{-1}, \mathrm{~B}^{-1}$.

Set the matrix in the command window of the program

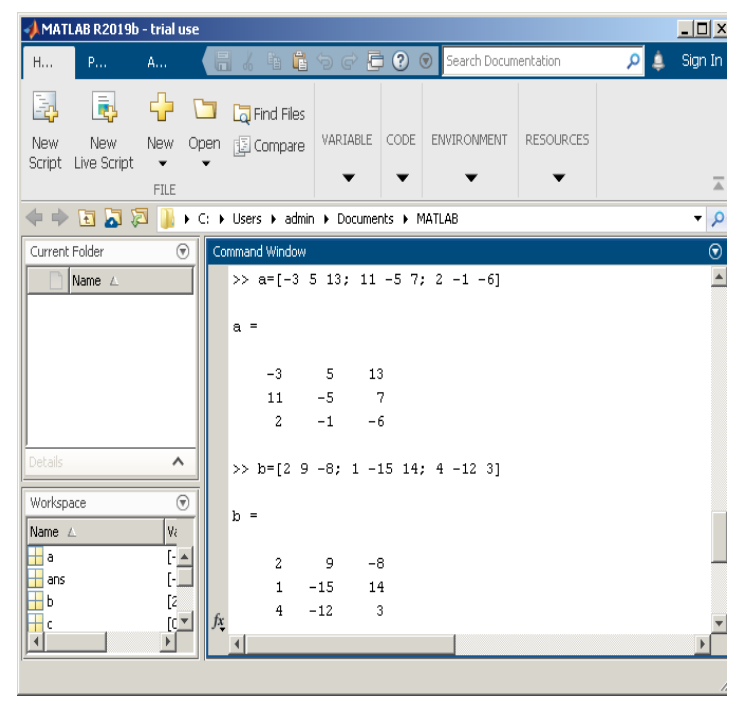

Fig. 1. Initial data

$$
\begin{gathered}
\mathrm{A}+\mathrm{B}=\left(\begin{array}{ccc}
-3 & 5 & 13 \\
11 & -5 & 7 \\
2 & -1 & -6
\end{array}\right)+\left(\begin{array}{ccc}
2 & 9 & -8 \\
1 & -15 & 14 \\
4 & -12 & 3
\end{array}\right)= \\
=\left(\begin{array}{ccc}
-3+2 & 5+9 & 13-8 \\
11+1 & -5-15 & 7+14 \\
2+4 & -1-12 & -6+3
\end{array}\right)= \\
\left(\begin{array}{ccc}
-1 & 14 & 5 \\
12 & -20 & 21 \\
6 & -13 & -3
\end{array}\right) .(2)
\end{gathered}
$$


Kotova O., Hryhorieva V., Hniedkova O. Linear algebra teaching using mathematics software packages

$$
\begin{aligned}
& =\left(\begin{array}{ccc}
-3+2 & 5+9 & 13-8 \\
11+1 & -5-15 & 7+14 \\
2+4 & -1-12 & -6+3
\end{array}\right)=\quad\left(\begin{array}{ccc}
-1 & 14 & 5 \\
12 & -20 & 21 \\
6 & -13 & -3
\end{array}\right) . \\
& A-B=\left(\begin{array}{ccc}
-3 & 5 & 13 \\
11 & -5 & 7 \\
2 & -1 & -6
\end{array}\right)-\left(\begin{array}{ccc}
2 & 9 & -8 \\
1 & -15 & 14 \\
4 & -12 & 3
\end{array}\right)= \\
& =\left(\begin{array}{ccc}
-3-2 & 5-9 & 13+8 \\
11-1 & -5+15 & 7-14 \\
2-4 & -1+12 & -6-3
\end{array}\right)= \\
& \left(\begin{array}{ccc}
-5 & -4 & 21 \\
10 & 10 & -7 \\
-2 & 11 & -9
\end{array}\right)
\end{aligned}
$$

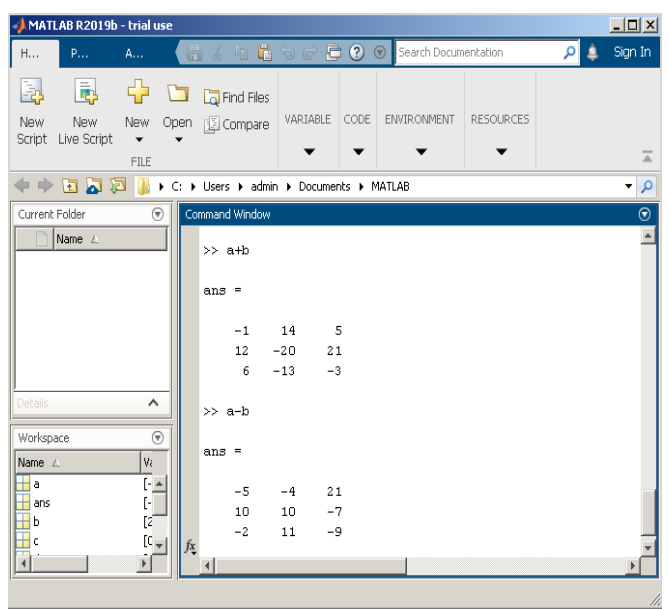

Fig. 2. Sum and disparity result

$\mathrm{c}_{11}=-3 \cdot 2+5 \cdot 1+\mathrm{c}_{12}=-3 \cdot 9+5 \cdot(-15)+\mathrm{c}_{13}=-3 \cdot(-8)+5 \cdot 14+13 \cdot 4=$

$$
51,+13 \cdot(-12)=-258,+13 \cdot 3=133, \quad \text { (4) }
$$$$
c_{21}=11 \cdot 2+(-5) \cdot 1+\mathrm{c} 22=11 \cdot 9+(-5) \cdot(-15)+
$$

$c_{23}=11 \cdot(-8)++7 \cdot 4=45+7 \cdot(-12)=90,+(-5) \cdot 14+7 \cdot 3=-137$.

$\mathrm{c} 31=2 \cdot 2+(-1) \cdot 1+\mathrm{c} 32=2 \cdot 9+(-1) \cdot(-15)+\mathrm{c} 33=-8 \cdot 2+(-1) \cdot 14+$

$+(-6) \cdot 4=-21,+(-6) \cdot(-12)=105,+(-6) \cdot 3=-48$. (5)

$$
\begin{gathered}
C=A \cdot B=\left(\begin{array}{ccc}
-3 & 5 & 13 \\
11 & -5 & 7 \\
2 & -1 & -6
\end{array}\right) \cdot\left(\begin{array}{ccc}
2 & 9 & -8 \\
1 & -15 & 14 \\
4 & -12 & 3
\end{array}\right)= \\
C=\left(\begin{array}{ccc}
51 & -258 & 133 \\
45 & 90 & -137 \\
-21 & 105 & -48
\end{array}\right)
\end{gathered}
$$

Similarly, we find

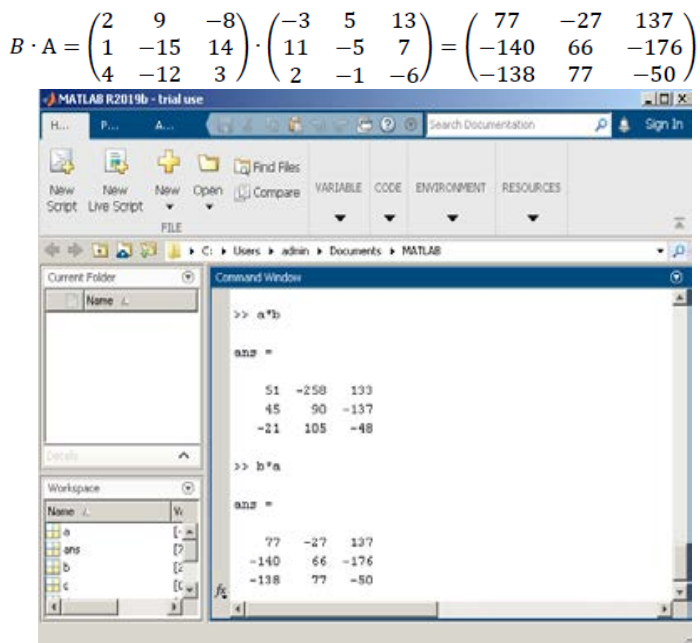

Fig. 3. Multiplication result

$$
|A|=\left|\begin{array}{ccc}
-3 & 5 & 13 \\
11 & -5 & 7 \\
2 & -1 & -6
\end{array}\right|=-3 \cdot(-5) \cdot(-6)+11 \cdot(-1) \cdot 13+5 \cdot 7 \cdot 2--(2 .
$$

$(-5) \cdot 13+11 \cdot 5 \cdot(-6)+7 \cdot(-1) \cdot(-3))=276$.

Similarly, we find

$$
|\mathrm{B}|=\left|\begin{array}{ccc}
2 & 9 & -8 \\
1 & -15 & 14 \\
4 & -12 & 3
\end{array}\right|=339
$$

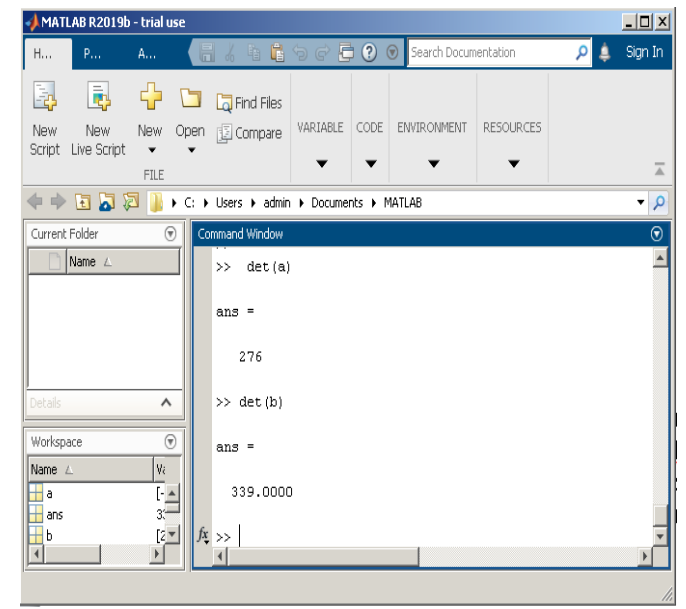

Fig. 4. Result of determinant finding

Find the algebraic complement of the matrix

$$
\begin{gathered}
A=\left(\begin{array}{ccc}
-3 & 5 & 13 \\
11 & -5 & 7 \\
2 & -1 & -6
\end{array}\right): \\
A_{11}=\left|\begin{array}{cc}
-5 & 7 \\
-1 & -6
\end{array}\right|=-5 \cdot(-6)-(-1) \cdot 7=37, \\
A_{12}=\left|\begin{array}{cc}
11 & 7 \\
2 & -6
\end{array}\right|=-80, A_{13}=\left|\begin{array}{cc}
11 & -5 \\
2 & -1
\end{array}\right|=-1, \\
A_{22}=\left|\begin{array}{cc}
-3 & 13 \\
2 & -6
\end{array}\right|=-8, A_{21}=\left|\begin{array}{cc}
5 & 13 \\
-1 & -6
\end{array}\right|=-17, A_{23}=\left|\begin{array}{cc}
-3 & 5 \\
2 & -1
\end{array}\right|=-7 \\
A_{31}=\left|\begin{array}{cc}
5 & 13 \\
-5 & 7
\end{array}\right|=100, A_{32}=\left|\begin{array}{cc}
-3 & 13 \\
11 & 7
\end{array}\right|=-164, A_{33}=\left|\begin{array}{cc}
-3 & 5 \\
11 & -5
\end{array}\right|=-40 . \\
A^{-1} \frac{1}{|A|}\left(\begin{array}{lll}
A_{11} & A_{21} & A_{31} \\
A_{12} & A_{22} & A_{32} \\
A_{13} & A_{23} & A_{33}
\end{array}\right)=\frac{1}{276}\left(\begin{array}{ccc}
37 & -17 & 100 \\
-80 & -8 & -164 \\
-1 & -7 & -40
\end{array}\right)
\end{gathered}
$$

Similarly, we find

$$
B^{-1}=\left(\begin{array}{ccc}
123 & 69 & 6 \\
53 & 38 & -36 \\
48 & 60 & -39
\end{array}\right)
$$

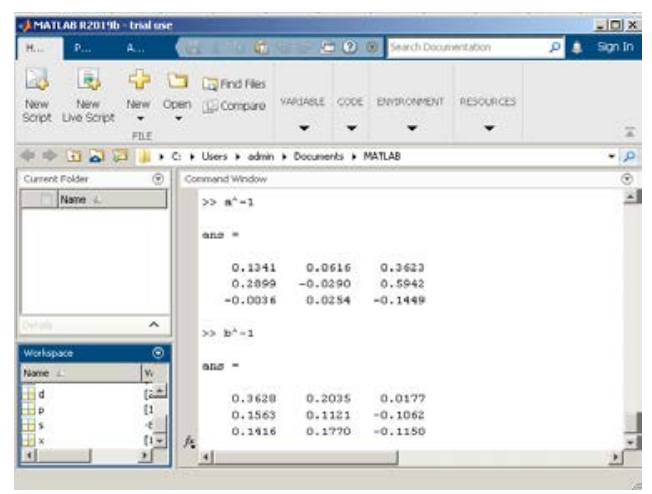

Fig. 5. The result of inverse matrix finding 
Linear equation system.

Let's system of linear equations are given:

$$
\begin{gathered}
\left\{\begin{array}{c}
a_{11} x_{1}+a_{12} x_{2}+\ldots+a_{1 n} x_{n}=c_{1} ; \\
a_{21} x_{1}+a_{22} x_{2}+\ldots+a_{2 n} x_{n}=c_{2} ; \\
\ldots \ldots \ldots \ldots \\
a_{n 1} x_{1}+a_{n 2} x_{2}+\ldots+a_{n n} x_{n}=c_{n} .
\end{array}\right. \\
\mathrm{A}=\left(\begin{array}{ccc}
a_{11} & \ldots & a_{1 n} \\
\ldots & \ldots & \ldots \\
a_{n 1} & \ldots & a_{n n}
\end{array}\right)-\text { matrix of coefficients; } \\
C=\left(\begin{array}{c}
c_{1} \\
\ldots \\
c_{n}
\end{array}\right)-\text { column vector of free members; } X=\left(\begin{array}{c}
x_{1} \\
\ldots \\
x_{n}
\end{array}\right)-\text { column vector of }
\end{gathered}
$$
unknowns.

Given $|A| \neq 0$, the system has a single solution.

Let's consider the matrix method. In matrix form, the system can be written as $A \cdot X=\mathrm{C}$ then $X=A^{-1} \cdot C$

\section{Example}

$$
\begin{aligned}
& A=\left(\begin{array}{ccc}
-3 & 5 & 13 \\
11 & -5 & 7 \\
2 & -1 & -6
\end{array}\right), \quad C=\left(\begin{array}{c}
46 \\
22 \\
-18
\end{array}\right) \\
& X=\frac{1}{276}\left(\begin{array}{ccc}
37 & -17 & 100 \\
-80 & -8 & -164 \\
-1 & -7 & -40
\end{array}\right) \cdot\left(\begin{array}{c}
46 \\
22 \\
-18
\end{array}\right)=\left(\begin{array}{l}
1 \\
2 \\
3
\end{array}\right)
\end{aligned}
$$

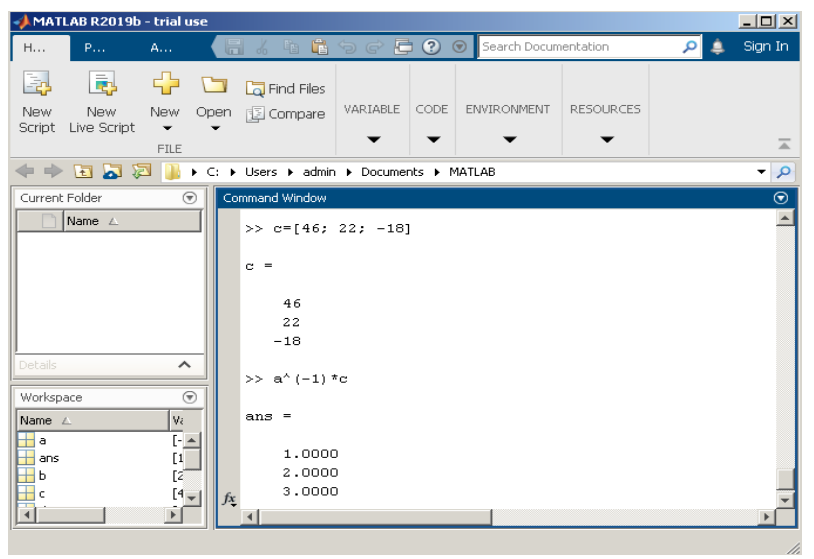

Fig. 6. The result of equation solution finding

Matlab supports working with complex numbers, which have significant applied value in Physics and Economics.

A complex variable in algebraic form is specified. The software provides the function of the imaginary part. So, for example, all the above-considered actions can be carried out in the field of complex numbers.

If the course of the solution is not important, then the command "alc" is used. To solve the system of linear equations by the Cramer method, it is necessary: to set the main matrix of coefficients for unknowns; set auxiliary matrices; calculate unknown systems of equations by dividing the determinant of the corresponding auxiliary matrix by the determinant of the main matrix.

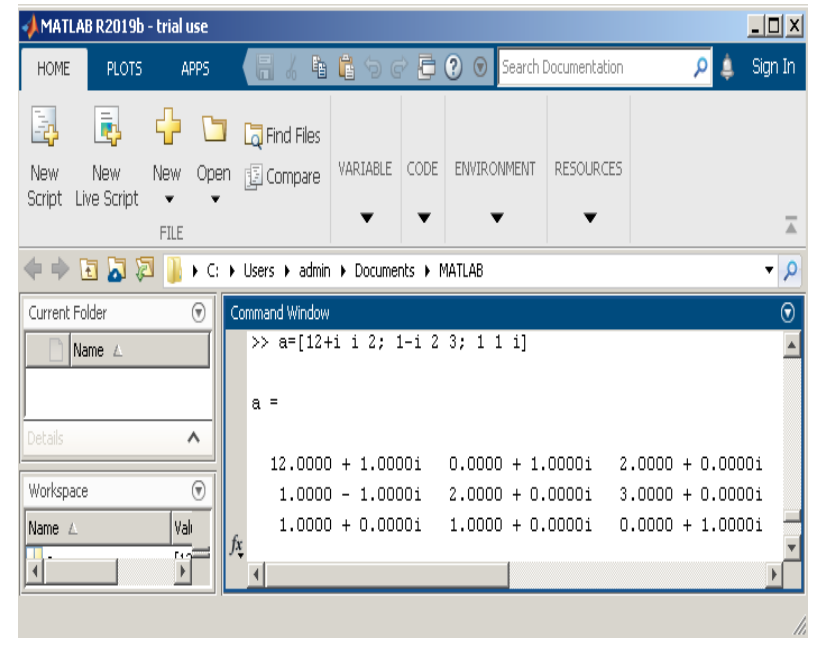

Fig. 7. Complex Variable Matrix

To solve linear systems or nonlinear equations, Matlab has a special solve function. It is necessary: to determine symbolic variables, calculate unknowns by the formula $[\mathrm{x} 1, \mathrm{x} 2, \ldots]=$ solve ('equation1', 'equation2', ...), derive the found solution with a given accuracy using the vpa function (variable, number of characters).

Graphical way.

The graphical method can be applied to systems of dimension 2 or 3 . It is necessary: to set symbolic variables, a function, design a function graph, add grid lines to the graph, use the graphic "magnifier" to scale the graph to achieve the required accuracy in determining the roots of the equation, the abscissas of the intersection points of the graph of the function are the roots of the equation.

Conclusion and prospective. One of the significant advantages of Matlab system is its integration into all areas of modern science and technology. Matlab is a global standard in higher education and research. The linear algebra teaching is based on the traditional presentation of the material. Matlab package application allows to increase the educational process efficiency and to form competencies necessary in future professional activities (Thomas S. Shores, 2000).

Students are open to all kinds of technologies in Mathematics. The openness and availability of hightech tools, is changing the approach to linear algebra teaching.

Currently, in many educational institutions the organizing forms of educational process are being reformed and distance learning is being intensively introduced. It requires the development of electronic 
textbooks and practical works. So, the task of increasing of the laboratory works efficiency by working only with Web browser is actual. Tools for remote development have appeared in some mathematical packages, including Matlab. Web application development is a special feature of Matlab to use remote computing for increasing of solving tasks efficiency. It greatly facilitates teachers' work and plays an important role in improving the effectiveness of educational organization tools and the distance learning introduction.

In the following papers, approaches to linear algebra study with the use of mathematical packages will be described.

\section{BIBLIOGRAPHY}

1. Wikipedia. URL: https://en.wikipedia.org/wiki/Cleve_Moler.

2. Terms of use - CC BY SA. URL: http://en.unesco.org/open-access/terms-use-ccbysa-en.

3. Technische Universiteit Eindhoven. An Introduction to Matlab and Mathcad Troy Siemers, Ph.D. Department of Mathematics and Computer Science Virginia Military Institute.

4. Copyright (C) 2011 Troy Siemers Licensed to the public under Creative Commons Attribution-Noncommercial 3.0 United States Licens. Introduction to Linear Algebra using MATLAB Tutorial on Material, Relevant to Linear Algebra By Stormy Attaway.

5. Stormy Attaway, MATLAB: A Practical Introduction to Programming and Problem Solving. Burlington, MA, Elsevier Inc., 2009.

6. Thomas S. Shores, Applied linear algebra and matrix analysis. 2000.

7. Matlab. URL: https://www.mathworks.com/products/matlab.html.

8. Simulink. Model Based and System Based Design. Using Simulink. The Math Works, Inc. USA, 2002.

9. Numerical Computing with MATLAB. The Math Works, Inc.

10. MATLAB. The Language of Technical Computing. Using MATLAB.The Math Works, Inc. USA, 2000.

11. Mathematics Stack Exchange user joriki.

12. William Kahan, Chiò's, Trick for Linear Equations with Integer Coefficients. 2012.

13. MATLAB for education. URL: https://exponenta.ru/academy/lectors.html.

14. MATLAB for Artificial Intelligence. URL: https://mathworks.com/products/matlab/live-editor.html.

\section{REFERENCES}

1. Wikipedia. Retrieved from: https://en.wikipedia.org/wiki/Cleve_Moler.

2. Terms of use - CC BY SA. Retrieved from: http://en.unesco.org/open-access/terms-use-ccbysa-en.

3. Technische Universiteit Eindhoven. An Introduction to Matlab and Mathcad Troy Siemers, Ph.D. Department of Mathematics and Computer Science Virginia Military Institute.

4. Copyright (C) 2011 Troy Siemers Licensed to the public under Creative Commons Attribution-Noncommercial 3.0 United States Licens. Introduction to Linear Algebra using MATLAB Tutorial on Material, Relevant to Linear Algebra By Stormy Attaway.

5. Stormy Attaway, MATLAB: A Practical Introduction to Programming and Problem Solving.Burlington, MA, Elsevier Inc., 2009.

6. Thomas S. Shores, Applied linear algebra and matrix analysis. 2000.

7. Matlab. Retrieved from: https://www.mathworks.com/products/matlab.html.

8. Simulink. Model Based and System Based Design. Using Simulink.The Math Works, Inc. USA, 2002.

9. Numerical Computing with MATLAB. The Math Works, Inc.

10. MATLAB. The Language of Technical Computing. Using MATLAB.The Math Works, Inc. USA, 2000.

11. Mathematics Stack Exchange user joriki.

12. William Kahan, Chiò's, Trick for Linear Equations with Integer Coefficients (2012).

13. MATLAB for education. Retrieved from: https://exponenta.ru/academy/lectors.html.

14. MATLAB for Artificial Intelligence. Retrieved from: https://mathworks.com/products/matlab/live-editor.html. 